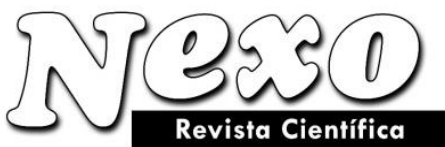

Vol. 33, No. 02, pp. 357-367/Diciembre 2020
ISSN-E 1995-9516

Universidad Nacional de Ingeniería COPYRIGHT @ (UNI). TODOS LOS DERECHOS RESERVADOS http://revistas.uni.edu.ni/index.php/Nexo https://doi.org/10.5377/nexo.v33i02.10774

\title{
Evaluating interventions for revitalization of urban decay of Jomhouri neighborhood of Tehran based on crisis management approach
}

\section{Evaluación de intervenciones para la revitalización de la decadencia urbana del barrio de Jomhouri de Teherán según el enfoque de gestión de crisis}

\author{
Hooman Rahimi ${ }^{1}$, Malihe Ahmadi* ${ }^{2}$ \\ 1 Department of Civil Engineering, College of Technical and Engineering, Shahr-e-Qods Branch, \\ Islamic Azad University, Tehran, Iran. \\ 2 Department of Urban Planning, College of Technical and Engineering, Shahr-e-Qods Branch, \\ Islamic Azad University, Tehran, Iran.
}

Corresponding Author Email:malihe_ahmadi2004@yahoo.com

(recibido/received: 01-May-2020; aceptado/accepted: 15-July-2020)

\begin{abstract}
Although urban decay of cities is important and valuable items; they are very vulnerable and unstable against natural disasters and on the other hands they are regarded as cultural capital and compressed buildings that are in fact treasury of social memories, methods of planning and life. The present research with the purpose of focusing on crisis management and describing its indices on revitalization of urban decay structure, examines the effective factors on revitalization of urban decay structure in Jomhouri neighborhood with the approach of crisis management. The research methodology from viewpoint of nature is descriptive- analytical and through comparing the defined indices obtained from theoretical fundamentals, the related data were analyzed by using statistical methods and SPSS software and also it is benefit from Expert Choice software. Through examining the effective factors for prioritizing intervention methods for decay structure the following 5 items based on priority were recognized and classified: Land adjustment of plaques (with final point of 0.79 ) as first priority, widening roads (with final point of 0.71 ) as second priority, consolidation of building (with final point of 0.57 ), reconstruction and granting bonus floor area ratio with points of 0.55 and 0.49 as fourth and fifth priority.
\end{abstract}

Keywords: Regeneration, Urban Decay, Jomhouri Neighborhood of Tehran, Crisis Management, AHP Method 


\section{RESUMEN}

Aunque la decadencia urbana de las ciudades es un elemento importante y valioso; son muy vulnerables e inestables frente a los desastres naturales y, por otro lado, son considerados como capital cultural y edificios comprimidos que en realidad son un tesoro de recuerdos sociales, métodos de planificación y vida. La presente investigación con el objetivo de centrarse en la gestión de crisis y describir sus índices sobre la revitalización de la estructura de decadencia urbana, examina los factores efectivos sobre la revitalización de la estructura de decadencia urbana en el barrio de Jomhouri con el enfoque de gestión de crisis. La metodología de investigación desde el punto de vista de la naturaleza es descriptiva-analítica y mediante la comparación de los índices definidos obtenidos a partir de fundamentos teóricos, los datos relacionados se analizaron mediante el uso de métodos estadísticos y software SPSS y también se beneficia del software Expert Choice. Mediante el examen de los factores efectivos para priorizar los métodos de intervención para la estructura de descomposición, se reconocieron y clasificaron los siguientes 5 elementos basados en la prioridad: Ajuste de tierra de placas (con un punto final de 0.79 ) como primera prioridad, ensanchamiento de caminos (con un punto final de 0.71 ) como segundo prioridad, consolidación del edificio (con un punto final de 0.57), reconstrucción y otorgamiento de un bono de área de piso con puntos de 0.55 y 0.49 como cuarta y quinta prioridad.

Palabras clave: Regeneración, decadencia urbana, barrio de Jomhouri de Teherán, gestión de crisis, método AHP

\section{INTRODUCTIÓN}

Urban decay structures in addition to rare aesthetics, reviewing old memories and regarded as identity of cities, are still residences for living place of millions of people in different cities and villages. These urban decay structure in spite of having significant values, are very vulnerable against natural disasters in different cities of Iran and on the other hand, are regarded as cultural capital and compressed buildings that are in fact treasury of social memories, methods of planning and life. Urban decay structure due to being old and very vulnerable against natural disasters and lack of having urban installations are incompatible with modern requirements of citizens; thus, the native population living in this area are immigrated to other cities and generally low-income classes of society and rural people are living in urban decay structure and it accelerates the process of destructing urban decay. The general goals of this study for renewal, reconstruction and revitalization are including: Increasing level of social security for urban decay structure, turning urban decay structure to urban wealth for utilization, increasing safety level of urban decay structure against natural disasters like: earthquake, improving environmental quality and welfare of inhabitants of urban decay structure, creating equal growth opportunities for inhabitants of this area through eliminating urban decay structure and poverty cycle (fair social justice).

\section{MATERIALS AND METHODS}

The goal of this research is focusing on crisis management and describing related indices for revitalization of urban decay structure as most effective factor for revitalization and renewal of urban decay structure of Jomhouri neighborhood with crisis management approach. 


\section{Revitalization of Urban Decay Structure:}

It is referred to set of activities for improving urban spatial planning in short term (Mahdizadeh, 2007) and in fact revitalization is performed when relative decay of space is happened through performance (Pourahmad \& Meshkini Abolfazl, 2007). Meanwhile, the revitalization cycle of urban decay structure was begun through recognizing and separating urban decay neighborhoods and through renewal of old buildings and supplying suitable infrastructures and developing local access networks. It is to be noted that evaluating and determining the current status and maintaining buildings has great importance for renewal of urban decay structure (Parvaneh, 2004).

\section{CRISIS MANAGEMENT}

Crisis management is performance process and planning by governmental officials and executive governmental and public organizations through observation, analysis of crisis on integrated, comprehensive and arranged basis and by using available tools for prevention of crisis (Moghadasi \& Mousavi, 2003). In a general definition, the crisis management involves a series of continuous-dynamic operations and activities based on classic principles of management including: planning, organizing, leadership and control system (Taghvaee, 2006).

\section{METHODOLOGY}

The present research methodology from viewpoint of nature is descriptive- analytical for theoretical studies and benefiting library studies by using books, thesis and available articles in university libraries and related organizations and through recognizing topic, the statement of problem was recognized and in compliance with goals of research, the theoretical fundamentals are examined. The current theories for renewal and revitalization of urban decay structure are extracted and ability of putting these ideas in operation in case-study was examined and in the analysis, it was benefit from quantitative models. In order to determine the quality level of spatial planning, it was benefit from SWOT Analysis (Strengths, Weaknesses, Opportunities, and Threats). By using Analytical Hierarchy Process (AHP) model, the weight of each strategy is described. Through comparing the defined indices, the data are analyzed by using statistical methods and SPSS software and also Analytical Hierarchy Process (AHP) model and Expert Choice software.

\section{THEORETICAL CONCEPTS AND FUNDAMENTALS}

The image and concept of urban decay structure in diverse countries may be different in compliance with population, family, economic, social and spatial planning conditions. The urban decay structure is defined in Iran are referred to legal areas of cities that due to being old and spatial decay structure, lack of having access to vehicles, urban infrastructures, installations and services are very vulnerable and have low level of spatial, environmental and economic values. This urban decay due to poverty of inhabitants and owners are not able to be reconstructed (Hossein \& Hataminejad, 2006). Urban decay structure has abundant aspects that are correlated with each other and some of these aspects are related to properties and applications of buildings; meanwhile, they are related to other aspects as well. In relation to each of these aspects, the level of urban decay of each building is different (Martos, Pacheco-Torres, Ordóñez, \& JadraqueGago, 2016). Revitalization consists of set of activities for improving spatial planning in short- 
term i.e. revitalization is happened when there is relative urban decay of a space from viewpoint of performance. Revitalization is summarized in the following activities:

Recuperation: It means set of activities with minimum cost and interventions and creating optimum environmental living condition in urban space (Habibi \& Maghsoudi, 2012).

Preservation: It means maintaining, preventing danger and damages to spatial planning and selecting suitable strategies for prevention of probable dangers. Some of the most important items of preservation are including: Inspection, regular control, repair and maintenance, studying deformations of structures, recognizing probable dangers and damages due to urban decay of space and building $(18,19)$.

Protection: It means creating suitable conditions for maintaining permanent urban space that consists of following items: preparing and enacting rules, attracting governmental support, determining protection fields and repair activities (Adibzadeh \& Hosseini, 2008).

Consolidation: It refers to set of activities for increasing security, power and strength of space or building (Majedi, 2010).

Rehabilitation: It means revitalization, reconstruction and renewal of an old structure through using new activities in old space

Improvement: It refers to set of activities for improving positive aspects and weakening negative aspects of space by focusing on using potential and actual activities in space and building with the purpose of reducing limitations and shortages.

According to the aforesaid items, revitalization is a process for improving status of space and building or changing performance and contemporizing and creating suitable spatial organization. The process of revitalization is shown in the following diagram (Habibi and Maghsoudi 2012)

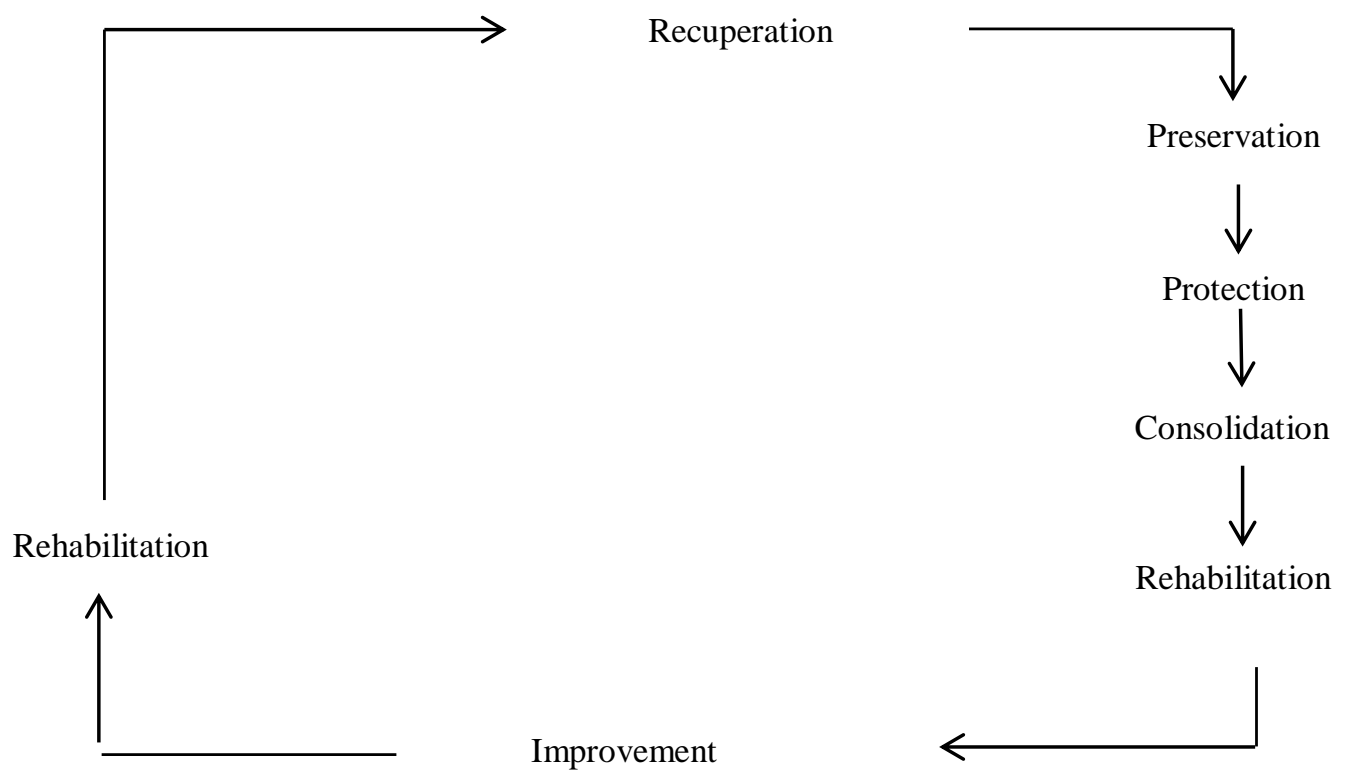

Figure 1. Diagram for Recuperation process, Habibi 2012, 19

\section{INTERVENTION ACTIVITIES FOR REPAIRING URBAN STRUCTURES}

The intervention in urban decay structure is performed through spatial planning, social and economic fields and some of the most important interventions for repair and amend of urban decay structure are offered. 
Consolidation: The fundamental goal is increasing strength and integrity of structure and spatial planning and in scale of city and urban set, it refers to consolidation of spatial structure of buildings (Habibi 2009).

In this method, the building lots are neither accumulated nor are turned into joint ownership; rather, through maintaining ownership and scope of lands it is permitted for the inhabitants for improving the quality of residential building and compensating small structures and increasing number of floors of residential units.

Land Adjustment: This method is recommended when neither available buildings in structure are valuable, nor they don't represent valuable urban elements and also due to being urban decay structure and other problems, they are useless (Endalib 2008)

Widening Roads: In narrow roads that are difficult for reaching to center of structure and widening roads is one of the methods for revitalization and renewal. Although widening roads is one of the challenging solutions and increases contradictions for revitalization and renewal of buildings for governmental authorities; for impermeable structures, this is regarded as the only method for improving easy access and offering rescue services (Endalib 2008).

Table1. Theories and Ideas of Scientists for Revitalization and Renewal of Urban Decay Structures:

\begin{tabular}{|c|c|c|c|c|}
\hline Name of Scientist & Time & Goal & Method & Intervention Type \\
\hline Camillo Sitte & $1843-1903$ & $\begin{array}{l}\text { 1- Searching the fundamentals } \\
\text { of ancient city construction for } \\
\text { new urban planning 2- Value of } \\
\text { historical buildings for spatial } \\
\text { communication and arrangement } \\
\text { between building and surround } \\
\text { environment } 3 \text { - Reconstruction } \\
\text { of urban planning rules at each } \\
\text { period } 4 \text { - Definition of historical } \\
\text { identity of city }\end{array}$ & $\begin{array}{lr}\text { Improvement } & \text { and } \\
\text { revitalization and less } \\
\text { attention }\end{array}$ & $\begin{array}{l}\text { Application with the } \\
\text { goal of continuing } \\
\text { historical and spatial } \\
\text { planning of urban } \\
\text { structure Improvement } \\
\text { and revitalization }\end{array}$ \\
\hline Leonardo Benevolo & 1939 & $\begin{array}{l}\text { 1- Historical continuity 2- } \\
\text { Balance and discrimination 3- } \\
\text { Presence of contemporary } \\
\text { structure and performance in old } \\
\text { buildings }\end{array}$ & Reconstruction & $\begin{array}{l}\text { Contemporizing with } \\
\text { reconstruction for } \\
\text { intervention based on } \\
\text { protection-ornamental } \\
\text { method }\end{array}$ \\
\hline Gustavo Giovanni & & Improving performance of city & $\begin{array}{l}\text { Improvement and } \\
\text { revitalization }\end{array}$ & $\begin{array}{l}\text { Intervention in urban } \\
\text { decay with the goal of } \\
\text { improving performance } \\
\text { of city by respecting to } \\
\text { live spatial planning } \\
\text { based on urban } \\
\text { reconstruction r for } \\
\text { comprehensive repair } \\
\text { plan of city }\end{array}$ \\
\hline Kevin A. Lynch & $1918-1984$ & $\begin{array}{l}\text { Creating continuity and } \\
\text { readability and revitalization in } \\
\text { old structure }\end{array}$ & $\begin{array}{l}\text { Taking action based on } \\
\text { designing city scenery } \\
\text { or metropolis }\end{array}$ & $\begin{array}{l}\text { Based on } \\
\text { comprehensive plan for } \\
\text { repair of city }\end{array}$ \\
\hline Christopher Alexander & 1936 & Organization deformities & $\begin{array}{l}\text { Reconstruction, renewal } \\
\text { and revitalizing based } \\
\text { on Contemporizing }\end{array}$ & $\begin{array}{l}\text { Based on } \\
\text { comprehensive plan for } \\
\text { repair of city }\end{array}$ \\
\hline Constantine Dokos & $1913-1975$ & $\begin{array}{l}\text { With the purpose of evaluating } \\
\text { protection, improvement, } \\
\text { reconstruction with previous } \\
\text { performance, determining level } \\
\text { of responsiveness and } \\
\text { satisfaction of inhabitants for } \\
\text { meeting daily requirements }\end{array}$ & $\begin{array}{l}\text { Reconstruction, renewal } \\
\text { and revitalizing and } \\
\text { recommended } \\
\text { Contemporizing }\end{array}$ & $\begin{array}{l}\text { Based on } \\
\text { comprehensive plan for } \\
\text { repair of city }\end{array}$ \\
\hline
\end{tabular}


Table2. Experiences of Foreign countries

\begin{tabular}{|c|c|c|}
\hline Country & Goal & Activity \\
\hline Germany & $\begin{array}{l}\text { 1- Finding solution for creating suitable living conditions in } \\
\text { city for human beings, arrangement with old and new } \\
\text { lifestyle 2- Maintaining available inhabitants and increasing } \\
\text { public partnership and urban repair }\end{array}$ & $\begin{array}{l}\text { 1- Partnership of inhabitants } \\
2 \text { - Repair and reconstruction of } \\
\text { buildings } \\
\text { 3- Determining level of partnership } \\
\text { and materials rights of inhabitants }\end{array}$ \\
\hline USA & 1- Contemporizing 2- Increasing social-economic respect & $\begin{array}{l}\text { Integrated intervention of people } \\
\text { and local associations with different } \\
\text { organizations and local government } \\
\text { for executing plan of urban city of } \\
\text { Baltimore }\end{array}$ \\
\hline France & & $\begin{array}{l}\text { Repairing residential buildings at } \\
\text { building units that completely } \\
\text { demolished for being replaced by } \\
\text { new buildings }\end{array}$ \\
\hline Italy & $\begin{array}{l}\text { 1- Preparing urban planning for repairing urban decay } \\
\text { structure 2- Maintaining urban scenery and attractive parts } \\
\text { of old and contemporary city and related unique properties }\end{array}$ & $\begin{array}{l}\text { Constructing a new commercial } \\
\text { center at old part of city and } \\
\text { through constructing houses in old } \\
\text { part, to meeting the housing } \\
\text { requirements }\end{array}$ \\
\hline Turkey & $\begin{array}{l}\text { 1- Reviving historical identity of city as global city } 2- \\
\text { Prioritizing revitalizing and renewal plan for cities } 3- \\
\text { Improving economic potentials } 4 \text { - Focus on historical and } \\
\text { cultural role of city }\end{array}$ & $\begin{array}{l}\text { 1- Establishing tourism applications } \\
\text { and performances } \\
\text { 2- Finding relationship between } \\
\text { repair plan with upstream plans }\end{array}$ \\
\hline Brazil & $\begin{array}{l}\text { 1- Linear improvement of old city and its continuity 2- } \\
\text { Link between all elements and spaces inside of city 3- } \\
\text { Developing commercial and service sectors } 4 \text { - Focusing on } \\
\text { public transportation system 5- Maintaining cultural } \\
\text { heritage of city 6- Limitation for new constructions }\end{array}$ & $\begin{array}{l}\text { 1- Comprehensive planning for } \\
\text { meeting human requirements } \\
\text { 2- Continuous planning for } \\
\text { transportation network } \\
\text { 3- Destructing great part of city } \\
\text { after world war with the goal of } \\
\text { revitalizing urban space }\end{array}$ \\
\hline
\end{tabular}

Table3. Through concluding aforesaid principles, we obtain the following criterions and indices

\begin{tabular}{|l|l|}
\hline \multicolumn{1}{|c|}{ Criterion } & \\
\hline \multirow{4}{*}{ Economic incentives } & Price of land and housing \\
\cline { 2 - 2 } Crisis making factors & Level of family income \\
\hline \multirow{5}{*}{ Spatial balance } & Risk level \\
\cline { 2 - 2 } & Infiltration and access \\
\cline { 2 - 2 } & Quality of building \\
\cline { 2 - 2 } & Measuring area of plaques \\
\cline { 2 - 2 } & Level of green and open space \\
\cline { 2 - 2 } & Mass and space \\
\hline \multirow{5}{*}{ Public partnership } & level of literacy \\
\cline { 2 - 2 } & Level of persons working (employed) \\
\cline { 2 - 2 } & Ownership \\
\cline { 2 - 2 } & Application of lands \\
\hline & Compression of population \\
\cline { 2 - 2 } & No of floors \\
\cline { 2 - 2 } & Compression of family in residential units \\
\cline { 2 - 2 } & Population growth \\
\hline
\end{tabular}




\section{LOCATION OF JOMHOURI NEIGHBORHOOD}

Jomhouri neighborhood is located at neighborhood 1 of district.11 and county.3. From north it is limited to Azadi St, from south it is limited to Azerbaijan St, from west it is limited to Shahid Navab Safavi St and from east it is limited to Zare St and Golshan St and this neighborhood has area of $0.45 \mathrm{~km}$. The history of formation of this neighborhood goes back to Mohammad Reza Shah Pahlavi and development of Tehran from borders of Karegar St, construction of new buildings and residing ever-growing number of immigrants to Tehran and this neighborhood was turned into residential neighborhood.

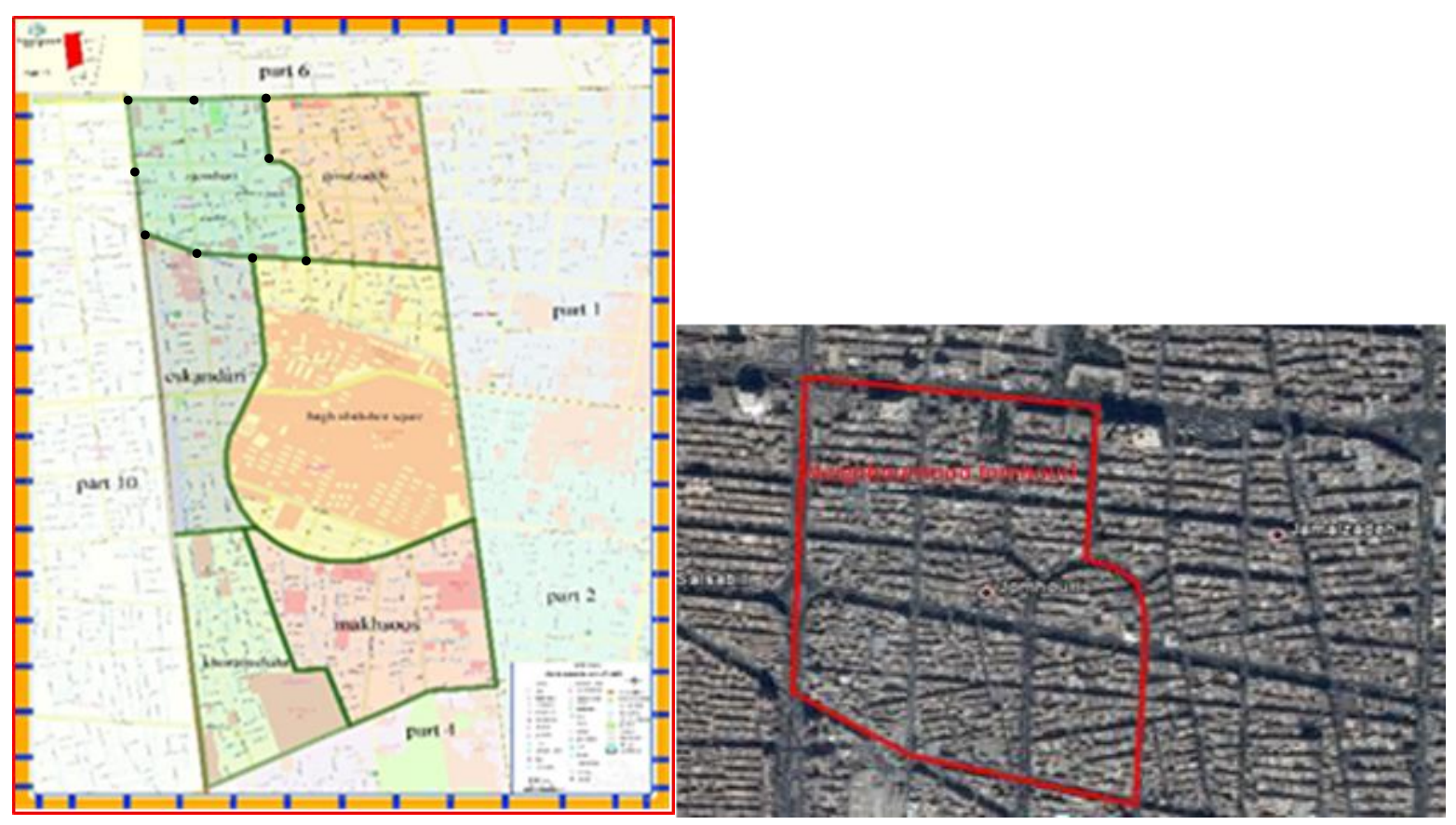

Figure 2. Jomhouri neighborhood

\section{Results:}

Analytical Hierarchy Process (AHP) is one of the most famous multi-index decision making methods that was invented by Thomas L. Saaty (1988). This method may be useful while decision making with several items and indices and the indices may be qualitative or quantitative and this method is based pairwise comparison and consists of following stages:

\section{Hierarchy Structure:}

In this stage, the problem is defined and the purpose of decision making is designed as hierarchy of factors and elements. The Analytical Hierarchy Process (AHP) requires breaking problem with several indices by hierarchy of levels i.e. it is benefit from tree consisting of 4 levels including: First level consists of goal, second level consists of criterions, third level consists of subcriterions (indices) and fourth level consists of items (intervention activities). The following diagram shows the hierarchy structure for intervention activities in Jomhouri neighborhood . 


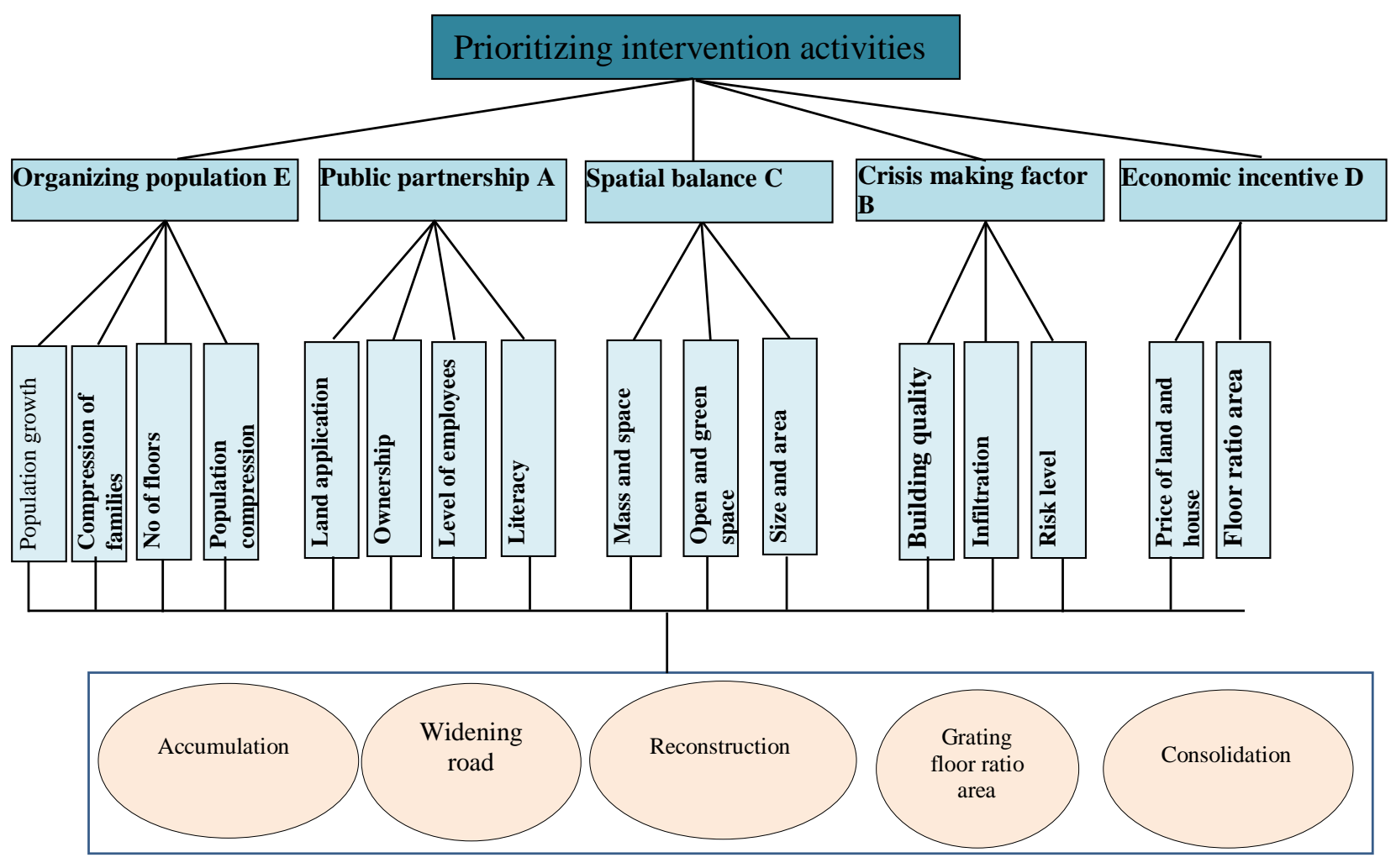

Figure 3. Diagram for hierarchy structure of prioritizing intervention activities in Jomhouri neighborhood

\section{PAIRWISE COMPARISON}

In this stage the experts and people grant point to indices and the weight of criterions are determined through pairwise comparison method. A table with 9 quantities is regarded as basis for comparison and according goal of investigations, aij the intensity of superiority of criterion $\mathrm{i}$ toward criterion $\mathrm{j}$ is determined; then all criterions are compared by pairwise mode. For facilitation of this task, the effective criterions for prioritizing urban decay structure is marked that is shown in figure 3. In next stage, a $5 \times 5$ matrix for comparison is established and is called matrix A and in this matrix, the importance of criterions toward each other based on comments of experts and people and comparison table with 9 quantities is estimated. 
Table 4. Importance of criterions for intervention of urban decay in neighborhoods

\begin{tabular}{|r|r|r|r|r|r|r|}
\hline & $\mathrm{A}$ & $\mathrm{B}$ & $\mathrm{C}$ & $\mathrm{D}$ & $\mathrm{E}$ & $\begin{array}{r}\text { Relative } \\
\text { Point }\end{array}$ \\
\hline $\mathrm{A}$ & 1 & 0.33 & 2 & 2 & 0.5 & 0.16 \\
\hline $\mathrm{B}$ & 3 & 1 & 3 & 3 & 1 & 0.34 \\
\hline $\mathrm{C}$ & 0.5 & 0.33 & 1 & 2 & 0.5 & 0.12 \\
\hline $\mathrm{D}$ & 0.5 & 0.33 & 0.5 & 1 & 0.5 & 0.09 \\
\hline $\mathrm{E}$ & 2 & 1 & 2 & 2 & 1 & 0.27 \\
\hline
\end{tabular}

\section{COMPATIBILITY OF JUDGMENT}

A mechanism is observed for incompatibility of judgments that is called I.R. that is obtained from dividing incompatibility index I.I to random index R.I and if this coefficient is lower or equal to 0.1 , the level of compatibility for judgment is acceptable; otherwise, it shall be revised in judgments i.e. pairwise comparison matrix for criterions shall be repeatedly established

Incompatibility index $\boldsymbol{I} . \boldsymbol{I}=\frac{\lambda_{\max }-\boldsymbol{n}}{\boldsymbol{n}-\mathbf{1}}$

After calculations it is necessary for compatibility of judgments

\section{DETERMINING IMPORTANCE OF INDICES}

In this stage in order to determine importance of indices and granting point to indices, it is benefit from Delphi method and in next stage, the standard point for indices in relation to intervention activities are calculated.

\begin{tabular}{|c|c|c|c|c|c|c|c|}
\hline \multirow{2}{*}{$\begin{array}{c}\text { Criterion } \\
\text { point }\end{array}$} & \multicolumn{5}{|c|}{ Intervention activities } & \multirow{2}{*}{ Index } & \multirow{2}{*}{ 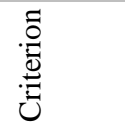 } \\
\hline & $\begin{array}{l}\text { Granting } \\
\text { floor ratio }\end{array}$ & Consolidation & Reconstruction & $\begin{array}{r}\text { Widening } \\
\text { road }\end{array}$ & $\begin{array}{c}\text { Accmulation } \\
\text { of plaques }\end{array}$ & & \\
\hline \multirow{3}{*}{0.09} & 0.18 & 0.23 & 0.18 & 0.18 & 0.23 & Economic ability & \multirow{2}{*}{ 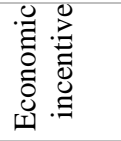 } \\
\hline & 0.20 & 0.10 & 0.10 & 0.20 & 0.40 & $\begin{array}{l}\text { Price of land and } \\
\text { house }\end{array}$ & \\
\hline & 0.38 & 0.33 & 0.28 & 0.28 & 0.63 & & Point \\
\hline \multirow{4}{*}{0.34} & 0.24 & 0.06 & 0.24 & 0.24 & 0.24 & Building quality & \multirow{3}{*}{ 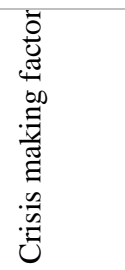 } \\
\hline & 0.13 & 0.22 & 0.22 & 0.22 & 0.22 & Risk level & \\
\hline & 0.06 & 0.22 & 0.17 & 0.28 & 0.28 & $\begin{array}{l}\text { Access and } \\
\text { infilteration }\end{array}$ & \\
\hline & 0.42 & 0.50 & 0.62 & 0.73 & 0.73 & & Point \\
\hline \multirow[b]{2}{*}{0.12} & 0.09 & 0.09 & 0.09 & 0.36 & 0.36 & Mass and space & \multirow{2}{*}{ 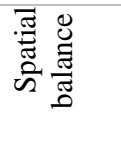 } \\
\hline & 0.13 & 0.13 & 0.13 & 0.38 & 0.25 & $\begin{array}{l}\text { Green and open } \\
\text { space }\end{array}$ & \\
\hline
\end{tabular}




\begin{tabular}{|c|c|c|c|c|c|c|c|}
\hline & 0.11 & 0.11 & 0.11 & 0.11 & 0.56 & Size and area & \\
\hline & 0.42 & 0.42 & 0.42 & 1.30 & 1.44 & \multicolumn{2}{|r|}{ Point } \\
\hline \multirow[t]{5}{*}{0.16} & 0.29 & 0.14 & 0.29 & 0.14 & 0.14 & Literacy & \multirow{4}{*}{ 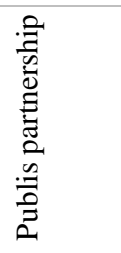 } \\
\hline & 0.20 & 0.10 & 0.20 & 0.20 & 0.30 & Ownership & \\
\hline & 0.25 & 0.25 & 0.17 & 0.17 & 0.17 & No of employees & \\
\hline & 0.15 & 0.15 & 0.23 & 0.23 & 0.23 & Application & \\
\hline & 0.89 & 0.65 & 0.88 & 0.74 & 0.84 & & Point \\
\hline \multirow[t]{5}{*}{0.27} & 0.19 & 0.25 & 0.25 & 0.13 & 0.19 & $\begin{array}{l}\text { Population } \\
\text { compression }\end{array}$ & \multirow{4}{*}{ 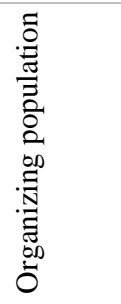 } \\
\hline & 0.12 & 0.29 & 0.12 & 0.29 & 0.18 & No of floors & \\
\hline & 0.08 & 0.08 & 0.17 & 0.25 & 0.42 & $\begin{array}{l}\text { Compression of } \\
\text { families }\end{array}$ & \\
\hline & 0.31 & 0.15 & 0.23 & 0.23 & 0.08 & Population growth & \\
\hline & 0.49 & 0.77 & 0.55 & 0.60 & 0.59 & & Point \\
\hline
\end{tabular}

\section{DETERMINING FINAL POINT (PRIORITY) OF CHOICES}

Upon calculating final point, the priorities are determined and are offered in table 6 respectively according to priority of urban decay in Jomhouri neighborhood.

Table 6: Final point for intervention method for urban decay in Jomhouri neighborhood

\begin{tabular}{|l|l|l|}
\hline \multicolumn{1}{|c|}{ Priority of activity } & \multicolumn{1}{|c|}{ Final point } & \multicolumn{1}{|c|}{ Type of activity } \\
\hline 1 & 0.79 & Accumulation of plaques \\
\hline 2 & 0.71 & Widening roads \\
\hline 3 & 0.57 & Consolidation of building \\
\hline 4 & 0.55 & Reconstruction \\
\hline 5 & 0.49 & Granting bonus floor ratio area \\
\hline
\end{tabular}

\section{DISCUSSION}

Focusing on factors creating crisis in urban decay structures is very effective on activities and intervention of such urban decay and prioritizing intervention activities in compliance with importance and necessity of their application, has important role for revitalizing urban decay. According to the points of table 6, it is concluded that intervention method of "accumulation" with point of 0.79 is regarded as first priority in Jomhouri neighborhood, "widening roads" with point of 0.71 is regarded as second rank, "consolidation of building" with point of 0.57 is regarded as third priority, "reconstruction" with point of 0.55 is regarded as fourth priority and "granting bonus floor ratio area" with point of 0.49 is regarded as fifth priority. Although accumulation is accompanied with abundant problems related to ownership and agreement of owners and conditions for accumulation of land lots are not easy; in compliance with properties of urban decay including: small parts, infiltration, poor building quality; it seems that the plan of accumulating land lots is logical and great amount of impermeability and plan of widening roads is at second priority and whereas approach of this research is crisis management; the conditions 
for renewal and revitalizing neighborhood is regarded as factor for prevention of crisis management. Upon referring to different methods of intervention in structure of neighborhood that is originated from analysis of previous research; it is necessary to mention that aforesaid interventions may not solitarily revitalize and reconstruct the urban decay structure; obtaining this goal shall be depending on using mixture of intervention activities.

\section{REFERENCES}

Adibzadeh, B., \& Hosseini, S. E. (2008). Modern approach for obtaining maximum urban decay (case-study for plan of urban appearance and scenery of western Nematabad).

Habibi, S. M., \& Maghsoudi, M. (2012). Urban repair. Publications of University of Tehran.

Hossein, K. K., \& Hataminejad, H. (2006). Planning for repairing historical structures of Yazd city. Faragostar

Mahdizadeh. (2007). Strategic planning for urban development (recent global experiences and its status in Iran). Payam Cinema publications.

Majedi, H. (2010). Urban decay structure for future. Paper presented at the Second national conference of revitalizing and reconstructing historical structure, Tehran.

Martos, A., Pacheco-Torres, R., Ordóñez, J., \& Jadraque-Gago, E. (2016). Towards successful environmental performance of sustainable cities: Intervening sectors. A review. Renewable and Sustainable Energy Reviews, 57, 479-495.

Moghadasi, S. H., \& Mousavi, A. (2003). Crisis management in Tehran, University of Tehran.

Parvaneh, S. a. (2004). Analyzing scenario for developing spatial planning in urban decay structure by using $3 D G I S$ models. (Master's Degree). Tehran.

Pourahmad, H. K., \& Meshkini Abolfazl, A. (2007). Revitalizing and renewal of urban decay structure: Entekhab.

Taghvaee, A. A. (2006). Crisis management in cities. Paper presented at the national conference of earthquake crisis management in cities with historical structure, Yazd university. 